\title{
O JULGAMENTO DO HABEAS CORPUS 126.292/SP PELO SUPREMO TRIBUNAL FEDERAL SOB A ÓTICA DO PENSAMENTO DE NEIL MACCORMICK SOBRE ARGUMENTAÇÃO DA DECISÃO JUDICIAL
}

\author{
Martonio Mont'Alverne Barreto Lima ${ }^{1}$ \\ Rafael Gonçalves Mota ${ }^{2}$
}

\section{Resumo}

O artigo analisa o julgamento da ação de habeas corpus 126.292/SP pelo Supremo Tribunal Federal, ocorrido em 17 de fevereiro de 2016, no qual, a partir do exame do conceito e dos limites do princípio da presunção do estado de inocência, passou-se a admitir a execução da pena após a decisão confirmatória da condenação pelo juízo de segundo grau. O estudo apresentado toma como referência a teoria de argumentação de Neil MacCormick, especialmente considerando que o acórdão atende aos elementos essenciais que devem constar em uma decisão judicial, quais sejam, consistência, coerência e universalidade. Inicialmente, disserta-se sobre o conceito do princípio da presunção de inocência, bem como sua natureza jurídica. No segundo tópico do artigo, busca-se resumir o teor da decisão em estudo, para a seguir ponderar acerca dos argumentos contidos nos votos dos ministros, para posteriormente analisar os termos do acórdão sob o prisma do proposto por Neil MacCormick. Conclui-se que a decisão atende ao requisito da universalidade, porém não satisfaz plenamente aos requisitos da coerência e consistência, especialmente considerando ter sido tomada por maioria de votos bem como com a análise dos argumentos nela contidos. A metodologia utilizada é bibliográfica, doutrinária, legislativa e jurisprudencial.

Palavras-chave: Presunção de inocência; Execução Penal; Condenação Penal.

\section{INTRODUÇÃO}

O princípio da presunção de inocência, bem como seu alcance e limites, sempre foi objeto de análises e discussões em juízo, especialmente no que se refere a sua compatibilidade com as prisões cautelares, bem como a sua relação com a execução penal. Apontar o momento preciso no qual a execução da pena pode ser iniciada tomando como base tal princípio tornou o estudo da matéria ainda mais relevante.

Na visão dominante no Supremo Tribunal Federal - STF -, a presunção de inocência, esculpida no texto

\footnotetext{
${ }^{1}$ Professor Titular da Universidade de Fortaleza e Procurador do Município de Fortaleza. E-mail: barreto@unifor.br

2 Auxiliar da Universidade de Fortaleza e Doutorando em Direito pela Universidade de Fortaleza. Professor Assistente da Faculdade Ari de Sá (Fortaleza/CE). Assessor de Desembargador no Tribunal de Justiça do Estado do Ceará. E-mail: rafaelgmota@yahoo.com.br
} 
constitucional de 1988 não impedia, até o ano de 2009, a execução imediata da pena após a confirmação da condenação pelo juízo de segundo grau. Tal entendimento foi modificado no citado ano: o STF adotou postura mais radical, pelo qual a interpretação do princípio deveria ser feita de forma a entender que somente depois de transitada em julgado a decisão que condenou o réu seria possível se iniciar a execução penal. Em 2016, mais uma mudança na interpretação jurisprudencial e pela qual o STF volta a considerar possível a aplicação imediata de pena, bastando para isso apenas a observância do princípio do duplo grau de jurisdição, ou seja, confirmada a condenação pelo Tribunal de Justiça ou Tribunal Regional Federal, a pena pode ser executada.

O presente estudo analisa a decisão tomada quando o julgamento da ação de Habeas Corpus no 126.292/SP - HC no 126.292/SP - julgada em 17 de fevereiro de 2016, que, por maioria de sete votos a quatro, passou a permitir o início do cumprimento da pena superados dois graus de jurisdição e onde tenha sobressaído o juízo de condenação ao réu. $\mathrm{O}$ enfoque do presente artigo é a analise do acórdão tomando-se como referência a teoria de argumentação e interpretação de Neil MacCormick, buscando-se analisar se a citada decisão guarda os requisitos essenciais da coerência, consistência e universalidade, que na visão do autor são fundamentais para a validade e eficácia de uma decisão judicial.

Inicialmente o artigo irá contextualizar a decisão, situando a visão do Supremo Tribunal sobre o princípio constitucional da presunção de inocência, em especial considerando que o Tribunal passou a adotar visões distintas e diferentes sobre a matéria, especialmente considerando que ora percebeu tal princípio com mais radicalidade, ora não viu nenhum impedimento para a aplicação imediata da sanção criminal imposta ou confirmada pelos juízos de segundo grau de jurisdição.

A seguir, explica-se o pensamento de Neil MacCormick, especialmente destacando os requisitos essenciais indicados para conferir validade e eficácia às decisões judiciais, notadamente de possuírem universalidade, coerência e consistência.

Por fim, passa-se a análise da decisão que julgou o habeas corpus no 126.292/SP, em cada um dos votos a integrarem o acórdão, para ao final definir se o mandamento judicial preenche, sob o olhar do citado autor, os requisitos fundamentais que possam dar a decisão a validade, eficiência e aplicabilidade esperadas de qualquer decisão judicial, especialmente daquelas oriundas da mais alta corte de jurisdição brasileira.

\section{O PRINCÍPIO DA PRESUNÇÃO DO ESTADO DE INOCENCIA E SUA INTERPRETAÇÃO PELO SUPREMO TRIBUNAL FEDERAL}

O princípio da presunção do estado de inocência está previsto na Constituição Federal de 1988 em seu art. $5^{\circ}$, quando o inciso LVII afirma que "ninguém será considerado culpado até o trânsito em julgado de sentença 
penal condenatória". Tal mandamento indica de forma precisa que a declaração completa e final de responsabilidade criminal fica condicionada a decisão penal que já não admita recurso.

Desde o século XVIII, o mandamento sobre a inocência foi positivado no Ocidente ${ }^{3}$ quando, em 26 de agosto de 1789, a Declaração dos Direitos do Homem e do Cidadão (2018, online) passa a indicar, em seu art. $9^{\circ}$ que "todo o acusado se presume inocente até ser declarado culpado e, se se julgar indispensável prendê-lo, todo o rigor não necessário à guarda da sua pessoa, deverá ser severamente reprimido pela Lei." Como explica Antônio Magalhães Gomes Filho (2003, p.122):

Essa fórmula já permitia entrever, pelo menos, um duplo significado do preceito declarado pela Assembléia Nacional Francesa como 'direito natural, inalienável e sagrado do homem': de um lado, regra processual segundo a qual o acusado não está obrigado a fornecer provas de sua inocência, pois esta é de antemão presumida; de outro, garantia que deve impedir a adoção de medidas restritivas da liberdade pessoal antes do reconhecimento da culpabilidade, salvo os casos de absoluta necessidade.

Na mesma toada, quase um século e meio depois, a Declaração Universal dos Direitos do Homem (2018, online) dispôs que "todo ser humano acusado de um ato delituoso tem o direito de ser presumido inocente até que a sua culpabilidade tenha sido provada de acordo com a lei, em julgamento público no qual the tenham sido asseguradas todas as garantias necessárias à sua defesa." O Pacto de São José da Costa Rica, internalizado no Brasil pelo Decreto Legislativo n ${ }^{6}$ 678/1992, indica que "toda pessoa acusada de delito tem direito a que se presuma sua inocência enquanto não se comprove legalmente sua culpa."

A Convenção Européia de Direitos Humanos (CEDH) igualmente dispõe sobre o princípio, indicando em seu art. 6.2 que "qualquer pessoa acusada de uma infração presume-se inocente enquanto a sua culpabilidade não tiver sido legalmente provada." (CONVENÇÃO..., 2018, online) ${ }^{4}$.

A estrutura proposta no texto constitucional atual segue, portanto, a mesma estrutura normativa dos

\footnotetext{
${ }^{3}$ Convém destacar que a positivação advinda com a Declaração Universal dos Direitos do Homem e do Cidadão é tida de forma majoritária com a primeira e mais significativa no direito ocidental, porém não se pode olvidar que já na Carta Magna de 1215 havia menção ao princípio (RAMOS, 2013, p. 173). A normatização francesa ganha, no entanto, importância capital por ter sido mais expressa e pelo momento histórico, qual seja, a estabilização moderna do conceito de estado.

${ }^{4}$ Comentando a CEDH, Victor Moreno Catena (2015, p. 104) indica os oito pontos nos quais pode ser resumida a jurisprudência do Tribunal Europeu de Direitos Humanos: i) presunção de inocência só se aplica a favor da pessoa contra quem se apresentaram queixas; ii) o acusado deve ser tratado como se não tivesse cometido qualquer infração até que o Estado, por meio das autoridades responsáveis pelo exercício $d$ ação penal, apresente provas suficientes para que um tribunal independente e imparcial o declare culpado; iii) a presunção de inocência requer que os membros do tribunal não tenham uma ideia preconcebida de o acusado tenha cometido a infração da qual é acusado; iv) não se deve produzir qualquer pronunciamento judicial sobre a culpabilidade do acusado antes de este ter sido declarado culpado por um tribunal; iv) o acusado não poderá ser detido em regime de prisão preventiva salvo por motivos excepcionais e, se o for, desfrutará de condições de detenção adequadas à sua presumível inocência; vi) a carga da prova da culpabilidade recai sobre o Estado, e qualquer dúvida será favorável ao acusado e este poderá negar-se a
} 
diplomas que o antecederam no plano internacional, e mesmo utilizando a expressão "culpado" e não "inocente" não perde sua força semântica. Trata-se, na verdade, de um princípio que independente de sua redação específica funcionará "como princípio básico de todo o sistema penal, na medida em que situa o processo penal entre parâmetros constitucionalmente admissíveis." (CATENA, 2015, p. 103)

Convém destacar que o Supremo Tribunal Federal em seus julgados utiliza como sinônimos o princípio da presunção de inocência e princípio da não culpabilidade 5 . Sobre a eventual diferença de alcance ou conteúdo de tais formulações, comenta Gisele Gondin Ramos (2013, p.175) que "a formulação negativa da ideia não se mostra nem de longe suficiente para justificar o seu esvaziamento, muito menos a afeta em sua projeção sobre o ordenamento jurídico." Este dispositivo representa importante limitação ao poder do Estado ${ }^{6}$, notadamente quando se entende que a persecução criminal estatal deve ser dirigida a provar de forma inequívoca a culpa do agente, diante das consequências advindas para a liberdade individual. Assim, desde o início do desenvolvimento de sua ideia, a presunção de inocência impunha a exigência não apenas a exigência imposta à acusação de "uma prova absoluta (ou beyond a reasonable doubt) da culpa do réu, mas também para se assegurar a necessidade da existência condicional de um processo sempre que se procurasse condenar por algum crime." (SCANDERALI, 2008, p. 408).

Na mesma linha, qual seja, a necessidade de processo justo como decorrência da aplicação do princípio da presunção, indica Victor Moreno Catena (2015, p.103) que "o processo penal é regido por um princípio que deve ser permanentemente respeitado, desde o seu início até a decisão judicial transitada em julgado: a presunção de inocência”.

É impossível desconectar o conceito da presunção de inocência com a própria garantia da liberdade. O mandamento que impõe a declaração de culpa plena apenas empós a condenação definitiva no âmbito penal representa, ante tudo, uma limitação ao poder de punir do Estado, impondo a este a produção de uma prova segura e efetiva de culpabilidade do agente. Assim, a presunção de inocência tanto deve ser vista como uma regra de julgamento, quanto uma regra de tratamento do argüido. (CATENA, 2015, p. 103).

Tratando da mesma ideia, qual seja, conflito entre direito de punir e a liberdade tem-se que "a presunção de

responder às perguntas; vii) geralmente, não será exigido ao acusado que apresente provas autoincriminatórias e viii) os seus bens só poderão ser embargados mediante processo adequado.

${ }^{5}$ Neste sentido interessante a lição de Gustavo Britta Scandelari (2008, p. 410), ao afirmar que "descabe, portanto, dizer que não existiria presunção de inocência no ordenamento pátrio, mas sim presunção de não-culpabilidade. Os partidários dessa opinião se embasam numa rígida análise positivista-literal do art. 50, LVII, da CF/88, cujo texto não menciona a palavra inocente, mas culpado."

${ }^{6}$ Como leciona Antônio Scarance Fernandes (2005, p. 13) "na evolução do relacionamento indivíduo-Estado, houve necessidade de normas que garantissem os direitos fundamentais do ser humano contra o forte poder estatal intervencionista. Para isso, os países inseriram em suas Constituições regras de cunho garantista, que impõem ao Estado e à própria sociedade o respeito aos direitos individuais." 
inocência, enquanto princípio constitucional geral é mais um elemento de promoção do necessário equilíbrio do cidadão (jus libertatis) e a prerrogativa estatal de punir eventuais infratores (jus puniendi)." (RAMOS, 2013, p. 177)

Oportuno destacar que o próprio direito a um processo justo e minimamente fundamentado em provas concretas, é pressuposto conceitual do princípio da presunção de inocência. Explicando melhor, não há como redundar em uma decisão justa que declare a culpabilidade do agente se não se percorrer uma estrada de provas idôneas, válidas e legais. O processo justo é o antecedente necessário da sentença legítima. Nesse sentido afirma Gustavo Britta Scandelari (2008, p.411):

Daí o moderno e humanitário entendimento de que, para que se processe criminalmente um sujeito de direitos, há de estar presente a condição da justa causa, que pode ser resumida como a reunião de indícios mínimos, sérios e concretos, da autoria e materialidade do delito narrado na inicial, bem como da presença do elemento subjetivo (seja dolo ou culpa), no agir do acusado, caso contrário a denúncia não pode ser recebida pelo Judiciário. E, se ausente a justa causa e mesmo assim for recebida a peça pórtica, está configurado constrangimento ilegal por violação ao princípio da presunção de inocência, sanável pela via heróica do habeas corpus. Ou seja, não é só a liberdade de se locomover que está sob a guarida do preceito grave, mas todos os direitos do cidadão com ela relacionados.

Questão que sempre levantou contestações e dúvidas é o limite ou alcance deste princípio. Em outras palavras, em que momento ocorre a inversão de presunção sobre a inocência do réu, e em especial quando é possível o início da execução da pena. Na visão de Hugo de Brito Machado (2016, p. 39), comentando a redação constitucional brasileira, "pode-se entender que o trânsito em julgado, no caso, diz respeito à coisa julgada como garantia constitucional, e com isto se tem garantia de que a lei não poderá alterar regra punitiva, tornando-a mais abrangente".

Da promulgação da Constituição Federal de 1988 até 2009, o Supremo Tribunal Federal entendia que o princípio da presunção de inocência, assim como definido no texto constitucional, não impedia o início da execução da penal após a decisão condenatória ser confirmada pelo juízo de segundo grau. Com isso, entendia o Tribunal que o fato de existir previsão constitucional indicando que a culpabilidade somente seria declarada de forma definitiva quando da condenação passada em julgado, não haveria impedimento para que a sanção criminal fosse executada antes da ocorrência da coisa julgada.

Referido entendimento foi alterado na jurisprudência do Supremo Tribunal Federal quando do julgamento do habeas corpus $n^{\circ}$ 84.078/MG, sob a relatoria do Ministro Eros Grau, e julgado em 05 de fevereiro de 2009. Quando da citada decisão, o Supremo Tribunal Federal decidiu por sete votos a quatro que a 
interpretação do princípio da presunção de inocência deveria ser aplicado de forma absoluta, ou seja, a execução penal somente poderia ser admitida após o trânsito em julgado da decisão penal, enquanto a matéria penal não fosse alcançada pela coisa julgada. Com isso declarou-se a inconstitucionalidade da chamada execução antecipada da pena. O julgamento recebeu a seguinte ementa "Habeas Corpus. Inconstitucionalidade da chamada "execução antecipada da pena”. Art. $5^{\circ}$. LVII, da Constituição Federal do Brasil. Dignidade da Pessoa Humana. Art. $1^{\circ}$, III, da Constituição Federal."

O fundamento central da decisão foi o conflito entre o princípio da presunção de inocência e a possibilidade de execução imediata da pena, chegando o Tribunal ao entendimento (por maioria) de que o cumprimento da pena antes da decisão condenatória transitada em julgado reveste-se de definitividade, a ofender não apenas a presunção de não culpabilidade, mas também a dignidade humana. A partir desse momento, consolidou-se o entendimento de que a única prisão admitida antes do trânsito em julgado é aquela que possui natureza cautelar, provisória, portanto.

O entendimento vigorou na jurisprudência do Supremo Tribunal Federal até o recente julgado do HC no 126.292/SP, onde por maioria (novamente sete votos contra quatro, só que agora no sentido oposto), volta a Corte a adotar o entendimento anterior, não apenas tolerando a aplicação da pena logo depois da decisão de segundo grau que confirmou a decisão condenatória (ou mesmo condenou o réu reformando sentença absolutória anterior), como passou a considerar este posicionamento como regra. A prisão nesse momento passa a possuir natureza penal e não mais meramente processual (sujeita, portanto, aos requisitos legais que autorizam a prisão preventiva).

Apesar de não constituir objeto central do presente artigo analisar quais teriam sido os motivos precisos da mudança no entendimento do Supremo Tribunal Federal sobre a matéria entre o julgamento dos habeas corpus de no 84.078/MG e 126.292/SP, este ponto será doravante enfrentado, ainda que de forma breve. Não se pode esquecer que um dos possíveis fatores de inflexão do entendimento é a mudança na composição do Tribunal. Entre os anos de 2009 e 2016, a renovação dos membros do Supremo Tribunal Federal foi significativa fazendo com que no último julgamento citado tenham atuado seis novos ministros, o que significa a possiblidade de construção de uma nova maioria. Desses, cinco ministros votaram no sentido da mudança de entendimento, e

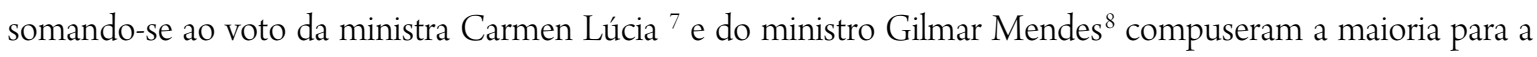

\footnotetext{
${ }^{7}$ A Ministra Cármen Lúcia manteve seu entendimento anterior de que não haveria incompatibilidade entre a execução da pena após a decisão do Tribunal de Segundo Grau que confirmou a sentença condenatória ou mesmo a que reformou decisão absolutória e impôs pena ao réu e o princípio da presunção de inocência. No julgamento de 2009 a Ministra aderiu ao entendimento que saiu vencida, no julgamento recente não.

${ }^{8} \mathrm{O}$ Ministro Gilmar Mendes mudou o seu entendimento entre os julgados de 2009 e 2016, passando a considerar de forma contundente a possibilidade de execução imediata de pena após o réu ser condenado por decisão do Tribunal de Justiça ou Tribunal Regional Federal.
} 
mudança na orientação jurisprudencial.

Nas tabelas seguintes está detalhado como cada um dos membros do Supremo Tribunal Federal votou nas duas ações de habeas corpus citadas, sendo possível concluir que, se a renovação da composição não pode ser apontada como uma explicação para a mudança de entendimento, porém não pode ser desconsiderada na análise, como se pode ver abaixo.

\begin{tabular}{|c|c|}
\hline \multicolumn{2}{|c|}{$\mathrm{HC} \mathrm{n}^{\circ} 84.078 / \mathrm{MG}$} \\
\hline \multicolumn{2}{|c|}{ Data de julgamento: 05 de fevereiro de 2009} \\
\hline Votaram pelo deferimento & Votaram pelo indeferimento \\
\hline da ordem ${ }^{9}$ & da ordem ${ }^{10}$ \\
\hline Min. Eros Grau (Relator) & \\
\hline Min. Gilmar Mendes ${ }^{11}$ & \\
\hline Min. Celso de Mello & \\
\hline Min. Marco Aurélio & Min. Cármen Lúcia \\
\hline Min. Cezar Peluso & Min. Joaquim Barbosa \\
\hline Min. Carlos Brito & Min. Ellen Gracie \\
\hline Min. Ricardo Lewandowski & \\
\hline
\end{tabular}

\begin{tabular}{|c|c|}
\hline \multicolumn{2}{|c|}{ HC no $^{\circ}$ 126.292/SP } \\
\hline \multicolumn{2}{|c|}{ Data de julgamento: 17 de fevereiro de 2016} \\
\hline Votaram pelo deferimento & Votaram pelo indeferimento \\
da ordem ${ }^{12}$ & da ordem ${ }^{13}$ \\
\hline Min. Rosa Weber & Min. Teori Zavascki (Relator) \\
\hline Min. Celso de Mello & Min. Gilmar Mendes \\
Min. Marco Aurélio & Min. Cármen Lúcia \\
Min. Ricardo Lewandowski & Min. Dias Toffoli \\
\hline
\end{tabular}

\footnotetext{
${ }^{9}$ Decidindo pela impossibilidade de execução penal imediata antes da decisão condenatória transitar em julgado. ${ }^{10}$ Decidindo pela possibilidade de execução imediata da pena antes da decisão condenatória transitar em julgado.

${ }^{11} \mathrm{Os}$ ministros grifados em negrito participaram de ambos os julgamentos. $\mathrm{O}$ único a modificar sua posição, de forma enfática, foi o Min. Gilmar Mendes.

${ }^{12}$ Decidindo pela impossibilidade de execução penal imediata antes da decisão condenatória transitar em julgado.

${ }^{13}$ Decidindo pela possibilidade de execução imediata da pena antes da decisão condenatória transitar em julgado.

${ }^{14} \mathrm{Os}$ ministros grifados em itálico não participaram do julgamento ocorrido em 2009 por ter sido nomeados e tomado posse no Supremo Tribunal Federal depois de fevereiro de 2009.
} 


\begin{tabular}{|c|c|}
\hline Min. Luiz Fux \\
Min. Roberto Barroso \\
Min. Edson Fachin \\
\hline
\end{tabular}

A decisão de 2016, por maioria, entendeu que o princípio da presunção de inocência não impede a aplicação da pena, tendo os ministros que conduziram o entendimento vencedor apontado diversos argumentos (constitucionais, legais e pragmáticos) que serão explorados em tópico próprio a seguir. Tais argumentos serão analisados e classificados com base na teoria argumentativa de Neil MacCormick. Antes da análise precisa dos votos dos ministros quando do julgamento do habeas corpus no 126.292/SP é necessário a explicação e contextualização faz-se necessários esclarecimentos.

\section{A TEORIA DE ARGUMENTAÇAO DE NEIL MACCORMICK}

No presente artigo analisa-se a decisão do Supremo Tribunal Federal no julgamento no habeas corpus $\mathrm{n}^{\circ}$ 126.292/SP sob a ótica do pensamento de Neil MacCormick no que tange a sua teoria de argumentação.

Tal teoria é fundamental para, na visão do autor, a correta aplicação do direito e a elaboração de decisões justas. Diante disso ele afirma que "uma teoria da argumentação jurídica exige uma teoria do direito e é exigida por esta" (MACCORMICK, 2006, p. 299). A correta aplicação das leis, portanto, está essencialmente conectada a uma adequada e precisa fórmula de argumentação e interpretação.

A teoria de Neil MacCormick (1999, p.103) busca verificar como a interpretação deve ser construída e influir na formação da decisão judicial, especialmente a relevância da argumentação para construção de um mandamento capaz de possuir validade e eficácia mínimas exigidas. Isso apresenta especial relevância quando tratamos de sistemas baseados no common law, já que "adquire vigência através das decisões dos tribunais cuja posição e independente do rei e do parlamento. ${ }^{15}$. Assim, a definição dos critérios pelos quais se pode verificar a validade e a eficiência de uma ordem judicial é fundamental no sistema de common law, já que a construção do direito passa pela edificação de um sistema judicial forte e harmônico. Tal percepção, no entanto, passa a ter igual relevância dos modelos baseados no chamado civil law, como o caso brasileiro. Isso é explicado pelo uso cada vez mais recorrente de precedentes no sistema judicial nacional, a exemplo das súmulas vinculantes ou mesmo a estrutura do novo Código de Processo Civil Brasileiro.

Um dos pontos iniciais indicados pelo autor é que o argumento de autoridade, comum no direito não é

\footnotetext{
${ }^{15}$ Tradução livre do texto original "adquiere vigencia a través de los fallos de los tribunales cuya posición es independiente del rey y del parlamento."
} 
mais suficiente para ser tomado como elemento central de fundamentação da decisão judicial. Para o autor, a idéia de que a norma ter sido produzida pelo Poder Legislativo, em tese legítimo, não pode servir de elemento que por si só gere validade para a decisão.

Como destaca Ana Maria D’Ávila Lopes e Márcio Benício (2015, p.40) a adequada e devida fundamentação é elemento essencial para conferir fundamento a uma decisão judicial em um Estado Democrático de Direito. Desta forma, um mandamento jurisdicional não deve ter apenas uma fundamentação qualquer, mesmo que seja por um elemento de autoridade mas deve levar em conta argumentos que possam, de forma precisa e segura conferir a validade e o fundamento. (MACCORMICK, 2010, p. 6).

É óbvio que nesta primeira premissa o abandono de pressupostos clássicos da teoria da democracia da modernidade parece ter sido utilizado: a relativização da soberania popular na democracia representativa traduz uma das mais significativas respostas aos dilemas da aplicação republicana do Direito, já que o princípio de que somos todos iguais perante as mesmas constituição e leis irrompe com a centralidade da igualdade para o conceito de democracia que hoje se requer. Aliás, é precisamente nas reflexões de MacCormick (2010) sobre soberania que se encontra, por um lado, sua forte inclinação para o nacionalismo inclusivo e tolerante, a ter como base uma sólida social democracia; e por outro lado, acham-se os questionamentos a enfrentarem o conceito tradicional de soberania.

Neil MacCormick (2010) indica alguns argumentos que deve compor decisão, em graus distintos, mas que com isso irão conferir eficácia e validade à decisão judicial. A seguir, tais argumentos serão indicados.

O primeiro dos argumentos é o argumento linguístico. Esse se divide em a princípio em duas categorias: os de natureza ordinária e os de significado técnico. Com isso tem-se elementos que são compreendidos como uso normal e regular da língua; porém outros somente serão compreendidos quando se verifica o uso técnico, ou seja, desprovidos de um mero significado comum ganham mais precisão. (MACCORMICK, 2010, p.70).

Como exemplo simples se pode indicar o conceito de casa. No Direito, utiliza-se o conceito ordinário de casa, sendo esse de domínio geral e não necessitando em geral de grandes elaborações teóricas. Há casos em que é necessário definir um conceito próprio e específico de casa do ponto de vista estritamente técnico-jurídico, quando se pretende chegar a uma finalidade própria. Com exemplo tem-se o disposto no parágrafo $4^{\circ}$ do artigo 150 do Código de Penal ${ }^{16}$, que ao definir o delito de violação de domićlio optou por um conceito próprio e mais abrangente de casa. Desta forma o que se compreende no sentido vulgar ou comum por casa não é o mesmo que

\footnotetext{
16 "S 40 - A expressão 'casa' compreende: I - qualquer compartimento habitado; II - aposento ocupado de habitação coletiva; III compartimento não aberto ao público, onde alguém exerce profissão ou atividade.”
} 
a assimilação técnica do Direito Penal definirá. ${ }^{17}$

Os argumentos lingüísticos têm peso, pois se alguém dotado de autoridade afirma algo ou define um conceito, como o legislador constituinte por exemplo, isso não deve ser ignorado ou mesmo não deve ser desconsiderado de início, já que a aplicação de argumentos lingüísticos passa também pela ideia de que se deve respeitar a vontade do legislador, ou seja, não deve o julgador a princípio mudar o significado original que o elaborador da norma conferiu a esse. Assim, o peso do argumento lingǘstico na construção de um argumento judicial, ou mesmo como elemento de fundamentação de uma decisão por um magistrado, deve ser considerado.

$\mathrm{Na}$ definição do autor, os argumentos sistêmicos devem ser compreendidos de forma que "se trata de un conjunto de argumentos que trabajan orientados hacia una comprensión aceptable de un texto jurídico visto particularmente como parte de un sistema jurídico". (MACCORMICK, 2010, p. 71). Desta forma, a interpretação, visando uma argumentação, deve igualmente considerar o dispositivo normativo dentro do contexto em que foi criado ou desenvolvido, com isso, por exemplo, a aplicação de um dispositivo específico do Código Penal deve ser feita tomando-se como referência não apenas a disposto no artigo (argumento lingüístico ou literal), ou seja, o texto, mas também o contexto legal e constitucional em que foi criado, estruturado e desenvolvido.

Nestes termos, Neil MacCormick (2010, p.73) indica que "la interpretación no puede ser satisfatoriamente alcanzada a través de un sentido puramente lingüistico a menos que se tenga en mente todo el contexto". A percepção do texto vem do contexto em que ele está inserido, devendo a interpretação do direito deve ser feita com base tanto na forma quanto no conteúdo.

Os argumentos sistêmicos podem ser classificados em: "argumento de la armonización contextual, argumento del precedente, argumento de analogia, argumento lógico-conceptual, argumentos de los princípios generales de derecho e argumento de la história”. (MACCORMICK, 2010, p. 74).

$\mathrm{O}$ argumento de harmonização contextual, o primeiro mais específico, traz o conceito mais diretamente ligado a idéia texto/contexto visto acima, e como explicam Ana Maria D`Ávila Lopes e Márcio Benício (2015, p. 42), quando "uma disposição legislativa pertence a um esquema superior e mais abrangente, portanto, deve ser interpretada não de forma isolada, mas em conformidade com ao qual tem relação mais próxima ou outra in pari matéria." Desta forma, a interpretação de determinado dispositivo legal deve ser feita tomando como base não apenas o sistema jurídico em que está inserida, mas especialmente os termos na norma constitucional que a fundamenta.

\footnotetext{
${ }^{17}$ Outro exemplo possível, ainda no âmbito do Direito Penal, envolve o conceito de funcionário público. Entendeu o legislador criminal que o significado imposto pelo Direito Administrativo não seria suficiente para alcançar todos os termos próprios da
} 
$\mathrm{O}$ argumento de precedente diz respeito a idéia de que uma interpretação dada por um juízo ou tribunal deve servir de referência para outras interpretações futuras, especialmente visando manter a coerência e integridade interpretativa, chegando a afirma o autor que "donde exista una doctrina del precedente basada en una jerarquía de los tribunales, el tribunal inferior debe someterse"(MACCORMICK, 2010, p. 72), ou nas palavras de Ana Maria D Ávila Lopes e Márcio Benício (2015, p.42) “deve-se procurar repetir a mesma interpretação que já foi dada a uma disposição por outros tribunais."

Como exemplos é possível citar o emprego das súmulas vinculantes a partir da Emenda Constitucional no 45 por meio da qual o Supremo Tribunal Federal, ao editar tais enunciados, impõe aos tribunais inferiores, julgadores monocráticos e até mesmo atores não jurídicos como delegados de polícia ${ }^{18}$, a observância limitada de algumas interpretações pré-estabelecidas e fruto de reiteradas decisões tomadas pela Corte Suprema. Da mesma forma a nova estrutura estimulada pelo novo Código de Processo Civil, a estimular com disciplina própria o uso dos precedentes judiciais.

O argumento de analogia está baseado na idéia de que se uma disposição legislativa é análoga, a outra pode ser utilizada para compor, complementar ou mesmo estender o conceito de outra, mesmo que importe em limitação de conceito ordinário anteriormente fixado e como complementa o autor, "la interpretación puede ser de la norma en si misma o derivada de una interpretación judicial previà. (MACCORMICK, 2010, p. 72).

$\mathrm{O}$ argumento lógico-conceitual é baseado na idéia de que um conceito definido em uma norma geral e reconhecida, quando aplicado de forma específica deve guardar sua estrutura ou significação central, mesmo utilizado de forma pontual e específica, ou seja, "cualquier concepto jurídico general reconocido y doctrinalmente elaborado es usado en la formulación de una disposición legislativa, debe ser interpretado de modo tal que se mantenga un uso consistente del mismo a través del sistema como un todo". (MACCORMICK, 2010, p.72).

$\mathrm{O}$ argumento dos princípios gerais de direito indica que "a interpretação de uma disposição legal deve manter coerência com o princípio geral aplicável ao caso" (LOPES; BENICIO, 2010, p.43). Com isso a interpretação a ser dada a uma norma ou enunciado legal é aquela que mais esteja em harmonia com o princípio geral de direito que a fundamenta ou dá suporte, ou ainda, que esteja de alguma forma ligada. Melhor interpretação da norma é aquela de acordo com o princípio da sustenta ontologicamente.

Por fim o argumento histórico pelo qual a interpretação de uma lei ou sistema de leis feita em determinado momento histórico deve influenciar e dirigir as compreensões de significado futuras para que com isso se

matéria penal, especialmente diante da necessidade de proteção mais ampla da máquina estatal, com isso é possível se visualizar interpretações lingüísticas mais técnicas, ou seja, de matizes mais específicas.

${ }^{18} \mathrm{Um}$ exemplo de súmula vinculante que deve ser observada por autoridades policiais é a de número 14 que indica que "é direito do defensor, no interesse do representado, ter acesso amplo aos elementos de prova que, já documentados em procedimento investigatório realizado por órgão com competência de polícia judiciária, digam respeito ao exercício do direito de defesa.”. 
mantenha a integridade e coerência interpretativas.

O último dos grupos de argumentos indicados pelo autor, em paralelo aos argumentos linguístico e sistêmicos, são os teleológicos e deontológicos, pelos quais se busca o significado pretendido pelo legislador quando da elaboração da norma, ou mesmo aqueles vinculados ao sentido mais correto do dispositivo, aqueles mais certos. Estão ligados a uma forma de interpretação substantiva. $\mathrm{O}$ autor indica que os argumentos interpretativos "teleológicos se refieren al fin o propósito que se imputa a un fragmento de legislación sobre la presunción de que ha sido promulgado por una legislatura racional en un determinado contexto histórico". (MACCORMICK, 2010, p. 74). Já o argumento interpretativo deontológico es un argumento en términos de princípios de rectitud o justicia, que debe ser observado en la perspectiva del intérprete con respecto a la situacion dada o asunto en cuestión (MACCORMICK, 2010, p. 74).

Desta forma, ao utilizar tais argumentos, o intérprete ou aplicador da norma busca qual o sentido último imaginado pelo legislador quando da criação da mesma, ou seja, qual era o objetivo principal ao definir o enunciado normativo, especialmente considerando (no caso dos argumentos deontológicos) aqueles que são mais justos ou corretos para com isso obter-se decisão ainda mais válidas e legítimas. Falando especificamente sobre o critério da validade, indica o autor que

Do ponto de vista de cada juiz, o que é aceito como critério de validade deve ser concebido por ele como uma norma social, não como uma norma puramente pessoal; concebido, quer dizer, como algo que estabelece o que está certo para que qualquer cidadão, aí incluídos ele mesmo e outros juízes, cumpra como lei válida. (MACCORMICK, 2006, p. 315).

O uso combinado desses grupos de argumentos pode gerar conflitos ou contradições, como lembram Ana Maria D `Ávila Lopes e Márcio Benício (2015, p.43), sugerindo Neil MacCormick que o uso hierarquizado dos argumentos com viso a evitar tais choques.

No tópico a seguir, serão analisados os termos dos votos dos ministros do Supremo Tribunal Federal com base nas categorias de argumentos sinalizados pelo autor escocês, para que se possa verificar se a decisão em seu conjunto geral apresenta a coerência, a consistência e a universalidade necessárias para gerar o maior grau de validade, legitimidade e eficiência possível.

\section{O HABEAS CORPUS No 126.292/SP E OS ARGUMENTOS INTERPRETATIVOS UTILIZADOS PELOS MINISTROS DO SUPREMO TRIBUNAL FEDERAL EM SEU JULGAMENTO}

Não é a primeira vez que se recorre a MacCormick para análises de decisões do Supremo Tribunal Federal. Ana Maria D’Ávila Lopes e Márcio Benício no artigo "Análise da decisão judicial sobre "briga de galos" vol.11, no. 03, Rio de Janeiro, 2018. pp. 1704-1733 
(ADIN no 1.856/2011) (2015), também partiram da Teoria Argumentativa de Neil MacCormick.

A escolha de tal técnica foi feita pelo caráter didático que a mesma propicia, especialmente considerando que é possível destacar de forma precisa quais os argumentos centrais utilizados por cada julgador ${ }^{19}$, especialmente considerando as ideias chaves, para a seguir se determinar o quanto coerente, consistente e universal é a decisão. Alguns dos julgadores não utilizaram em seus votos argumentos das três espécies tratadas, dessa forma, serão destacados os principais argumentos sem que necessariamente se possa sempre apontar todos pelo não uso dos mesmos.

Desta forma, inicialmente será feito um comentário geral sobre o voto de cada um dos julgadores, para, na forma de tabela, expor-se sinteticamente os principais argumentos tratados nos respectivos votos. Não foi realiza indicação dos argumentos da ementa do julgado em tabela própria já que a mesma é muito objetiva, pequena e precisa na sua construção.

No julgamento atuaram os onze ministros que compõe atualmente o STF, porém no acórdão constam os votos de dez dos julgadores, não existindo voto expresso no Ministro Dias Toffoli. Na certidão de julgamento consta expressamente que o mesmo estava presente e que não foi um dos julgadores que restaram vencidos, desta forma é seguro afirmar que o o Min. Dias Toffoli votou nos termos integrais do Ministro Relator. Com isso deixase de analisar o voto do citado Ministro Dias Toffoli por não constar no julgado. Serão analisados nos termos indicados os votos dos demais magistrados.

\section{Voto do Ministro Teori Zavascki}

O primeiro voto analisado é o do Ministro Teori Zavascki que funcionou como relator e que iniciou sua abordagem historiando o fato a ser julgado, destacando que o mesmo diz respeito a impugnação de decisão monocrática do Ministro Francisco Falcão, que na condição de presidente do Superior Tribunal de Justiça negou medida liminar pretendida.

O ponto inicial do voto foi a indicação de que pela relevância da matéria tratada, qual seja, a possibilidade de execução provisória de pena antes do trânsito em julgado da decisão condenatória penal, deveria ser superada, e, portanto, não aplicada, a súmula 691 do Tribunal Supremo que dispõe que "não compete ao STF conhecer de habeas corpus impetrado contra decisão do Relator que, em habeas corpus requerido a tribunal superior, indefere a liminar". Superado tal ponto o magistrado passou a desenvolver seus argumentos relacionados ao mérito, indicando que o tema tratado no writ envolvia reflexão sobre o princípio da presunção de inocência e a busca de um equilíbrio deste com a efetivação da função jurisdicional penal. 
A seguir desenvolve uma explicação histórica de como era e como estava o entendimento do Supremo Tribunal Federal sobre o tema, especialmente tratando da mudança de pensamento jurisdicional ocorrida em 2009. A seguir apresenta os argumentos que serão utilizados como fundamentadores de seu voto e que, de forma resumida, estão indicados na tabela abaixo.

Indica o magistrado que o enunciado que resume seu voto e que deve marcar o entendimento do Tribunal doravante é "a execução provisória de acórdão penal condenatória proferido em grau de apelação, ainda que sujeito a recurso especial ou extraordinário, não compromete o princípio constitucional da presunção de inocência." Desta forma sugere a restauração do entendimento adotado pelo Supremo Tribunal durante os anos de 1988 a 2009.

\begin{tabular}{|c|c|c|}
\hline \multicolumn{3}{|r|}{ Tabela 1} \\
\hline \multicolumn{3}{|r|}{ Ministro Teori Zavascki } \\
\hline Decisão & & $\begin{array}{l}\text { heceu a ação e denegou a ordem autorizando a execução da pena após a decisão } \\
\text { condenatória de segundo grau. }\end{array}$ \\
\hline $\begin{array}{l}\text { Páginas do } \\
\text { Acórdão }\end{array}$ & & 04 a 19 \\
\hline $\begin{array}{l}\text { Argumentos } \\
\text { Lingüísticos }\end{array}$ & & $\begin{array}{l}\text { O princípio da presunção de inocência está definido no texto constitucional no } \\
\text { art. } 5^{\circ} \text {, LVII da Constituição Federal e indica que "ninguém será considerado } \\
\text { culpado até o trânsito em julgado de sentença penal condenatória"; } \\
\text { o princípio do duplo grau de jurisdição não é absoluto e garante apenas a análise } \\
\text { da matéria fática por um juízo colegiado ao rever a decisão monocrática de acordo } \\
\text { com os termos da Constituição Federal e normais legais; } \\
\text { o art. } 637 \text { do Código de Processo Penal e art. } 27, \$ 22^{\circ} \text {, da Lei no } 8.038 / 1990 \\
\text { dispõem de forma expressa que o recurso extraordinário e o recurso especial não } \\
\text { possuem efeito suspensivo; } \\
\text { art. } 1^{\circ} \text {, I, da Lei Complementar no } 135 / 2010 \text { (Lei da Ficha Limpa) consagrou } \\
\text { como causa de inelegibilidade a existência de decisão condenatória proferida por } \\
\text { juízo colegiado. }\end{array}$ \\
\hline $\begin{array}{l}\text { Argumentos } \\
\text { Sistêmicos }\end{array}$ & & $\begin{array}{l}\text { A positivação do princípio no Brasil seguiu uma tendência mundial de proteção } \\
\text { dos direitos do réu e vem em harmonia com outros princípios como devido } \\
\text { processo legal, ampla defesa, contraditório, entre outros; } \\
\text { antes de prolatada a decisão condenatória deve o processo garantir a dúvida que } \\
\text { favorece ao réu, bem como uma presunção clara e efetiva de inocência em relação } \\
\text { ao acusado, porém a prolação da sentença que condena o mesmo representa "um } \\
\text { juízo de culpabilidade, que deve decorrer da logicidade extraída dos elementos de } \\
\text { prova produzidos em regime de contraditório no curso da ação penal"; (exemplo } \\
\text { de argumento lógico-conceitual); } \\
\text { no juízo de apelação fica exaurido o exame fático da acusação, exaurindo-se a } \\
\text { produção e análise de elementos probatórios e se consolidando a descrição e } \\
\text { definição do fato atribuído ao réu; } \\
\text { em regra, é nas "instâncias ordinárias que se exaure a possibilidade de exame de }\end{array}$ \\
\hline
\end{tabular}

${ }^{19} \mathrm{Em}$ alguns momentos optou-se pela transcrição literal dos argumentos trazidos pelo julgador para que não existisse a mínima possibilidade de perda do sentido original com citações indiretas ou reinterpretações. 


\begin{tabular}{|c|c|c|}
\hline & g) & $\begin{array}{l}\text { fatos e provas e, sob esse aspecto, a própria fixação de responsabilidade criminal } \\
\text { do acusado; } \\
\text { "com o julgamento implementado pelo Tribunal de Apelação, ocorre espécie de } \\
\text { preclusão da matéria envolvendo os fatos da causa”; (exemplo de argumento } \\
\text { lógico-conceitual); } \\
\text { a execução provisória de pena com a pendência de recurso especial e/ou } \\
\text { extraordinário "não compromete o núcleo essencial do pressuposto da não- } \\
\text { culpabilidade, na medida em que o acusado foi tratado como inocente no curso } \\
\text { de todo o processo ordinário criminal"; } \\
\text { indica que o entendimento utilizado no Brasil entre os anos de } 2009 \text { e } 2016 \\
\text { mostra-se em conflito ou desarmonia com aqueles desenvolvidos em outros } \\
\text { países do mundo, indicando como exemplo Inglaterra, Estados Unidos e outros; } \\
\text { (exemplo de argumento de analogia); } \\
\text { "a retomada da tradicional jurisprudência, de atribuir efeito apenas devolutivo aos } \\
\text { recursos especial e extraordinário (como, aliás, está previsto em textos } \\
\text { normativos) é, sob esse aspecto, mecanismo legítimo de harmonizar o princípio } \\
\text { da presunção de inocência com o da efetividade da função jurisdicional do } \\
\text { Estado." (exemplo de argumento de precedente). }\end{array}$ \\
\hline $\begin{array}{l}\text { Argumentos } \\
\text { Teleológicos- } \\
\text { Deontológicos }\end{array}$ & b) & $\begin{array}{l}\text { A implementação de um conjunto definido de princípios que protegem o réu que } \\
\text { é acusado de prática criminosa tem como objetivo dotar o processo penal de um } \\
\text { modelo mais racional e democrático; } \\
\text { o objeto principal dos recursos destinados aos tribunais superiores não é outro se } \\
\text { não a preservação do direito constitucional e federal, não possuindo como escopo } \\
\text { principal dotar o réu de um instrumento de reanálise de provas ou fato; }\end{array}$ \\
\hline
\end{tabular}

\section{Voto do Ministro Edson Fachin}

O segundo voto integrante do acórdão é do Ministro Edson Fachin, a iniciar por elogiar o voto do Ministro relator e indicar que irá aderir, porém pretende elaborar considerações complementares. A seguir, indica que o papel do Supremo Tribunal Federal é fazer com que a Constituição Federal seja salvaguardada e protegida, especialmente através da elaboração de teses jurídicas que possam dar ao texto constitucional maior segurança jurídica quando de sua aplicação, porém comenta que muitas vezes percebe a Corte Suprema com um certo "agigantamento dos afazeres" em face de um número crescente de demandas que chegam para lá serem deslindadas.

A seguir enumera, de forma mais sintética do que o relator já que adere integralmente ao voto desse, os argumentos que o levaram a decidir e que são sinteticamente indicados na tabela abaixo.

Tabela 2

Ministro Edson Fachin

Decisão

Conheceu e denegou a ordem autorizando a execução da pena após a decisão condenatória de segundo grau. 


\begin{tabular}{|c|c|c|}
\hline $\begin{array}{l}\text { Páginas do } \\
\text { Acórdão }\end{array}$ & 20 a 26 & \\
\hline $\begin{array}{l}\text { Argumentos } \\
\text { Lingüísticos }\end{array}$ & b) & $\begin{array}{l}\text { O princípio da presunção de inocência está definido no texto constitucional no } \\
\text { art. } 5^{\circ} \text {, LVII da Constituição Federal e indica que "ninguém será considerado } \\
\text { culpado até o trânsito em julgado de sentença penal condenatória"; } \\
\text { princípio da duração razoável do processo (art. } 5^{\circ} \text {, LXXVIII da Constituição } \\
\text { Federal) } \\
\text { o art. } 27, \$ 2^{\circ} \text {, da Lei no } 8.038 / 1990 \text { dispõe de forma expressa que o recurso } \\
\text { extraordinário e o recurso especial não possuem efeito suspensivo. }\end{array}$ \\
\hline $\begin{array}{c}\text { Argumentos } \\
\text { Sistêmicos }\end{array}$ & g) & 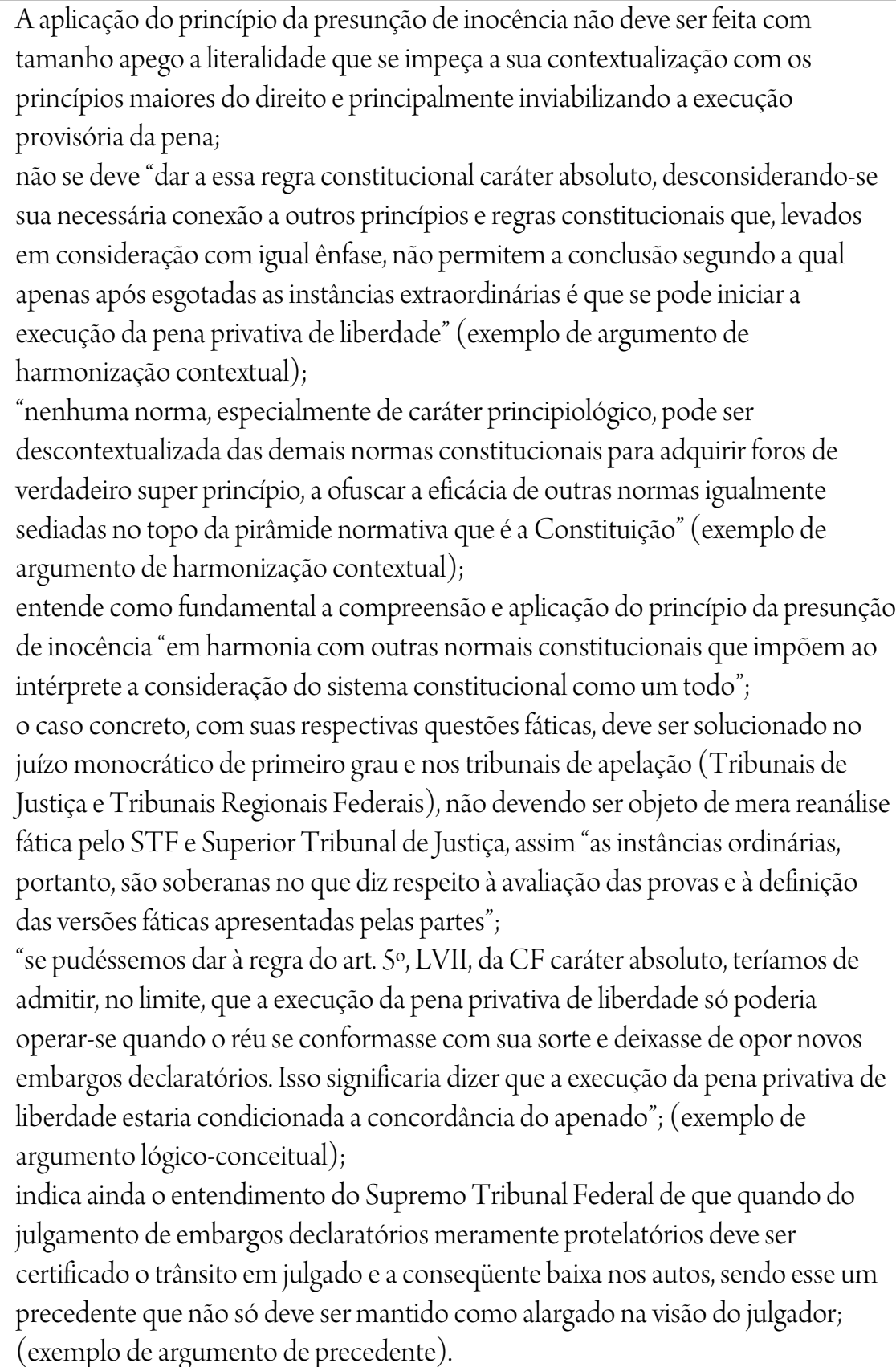 \\
\hline $\begin{array}{l}\text { Argumentos } \\
\text { Teleológicos- } \\
\text { Deontológicos }\end{array}$ & a) & $\begin{array}{l}\text { A função jurisdicional do Supremo Tribunal Federal e do Superior Tribunal de } \\
\text { Justiça é a preservação da ordem constitucional e da lei federal, respectivamente, } \\
\text { devendo conduzir seus julgados pelo desejo de preservação dessas e não tem }\end{array}$ \\
\hline
\end{tabular}


como objeto funcionarem como terceira ou quarta instâncias de jurisdição;

b) a Suprema Corte e do Superior Tribunal de Justiça devem "exercer seus papéis de estabilizadores, uniformizadores e pacificadores da interpretação das normas constitucionais e do direito infraconstitucional":

\section{Voto do Ministro Luís Roberto Barroso}

O voto seguinte constante do acórdão ora analisado é da lavra do Ministro Luís Roberto Barroso. Inicialmente o mesmo explica a estrutura utilizada no voto, indicando que o mesmo está dividido em três partes: a primeira cuida do "delineamento da controvérsia", a segunda "dos fundamentos jurídicos para a possibilidade de execução da condenação penal após a decisão do segundo grau" e a terceira e última parte, destinada a expor "os fundamentos pragmáticos para o novo entendimento".

O magistrado igualmente adere ao entendimento do Ministro relator, produzindo, no entanto, um voto ainda mais completo do que aquele, sendo o maior voto que compõe o acórdão. Indica não apenas argumentos e fundamentos constitucionais e legais para fundamentarem a mudança no entendimento do STF sobre a matéria em análise, com a consequente volta ao entendimento utilizado antes de 2009, como indica ainda argumentos que chama de "pragmáticos" que, entende, devem ser levados em consideração quando do julgamento e conseqüentemente fundamentarem a decisão.

Um dos argumentos interessantes destacados neste voto diz respeito a dados estatísticos informados pelo magistrado sobre os julgamentos dos recursos extraordinários feitos pelo Supremo Tribunal Federal nos últimos seis anos, mais precisamente entre $1^{\circ}$ de janeiro de 2009 e 19 de abril de $2016^{20}$, período em que a Corte aplicou o entendimento de que somente após o trânsito em julgado o réu pode ser compelido a cumprir a pena que the foi imposta. Das decisões proferidas em recursos especiais, somente foram providos 2,93\% (dois virgula noventa e três por cento) dos recursos, sendo que desses, apenas 1,12\% (um vírgula doze por cento) foram favoráveis ao réu. A maioria versou apenas sobre o regime prisional imposto ao réu, assim a eficácia precisa dos recursos para beneficiar o réu orbitam em menos de 1,5\% (um vírgula cinco por cento).

Como síntese maior de seu voto, a exemplo do que fez o Ministro Teori Zavascki, indica o Min. Barroso um enunciado que deve servir de referencial para balizar o novo entendimento do Tribunal, qual seja, "a execução de decisão penal condenatória proferida em segundo grau de jurisdição, ainda que sujeita a recurso especial ou extraordinário, não viola o princípio constitucional da presunção de inocência ou não culpabilidade”.

A seguir analisa-se os argumentos precisos indicados no voto com base nos elementos teóricos propostos

\footnotetext{
${ }^{20}$ Em seu voto, o Ministro Luís Roberto Barroso exibe dados produzidos pelo Assessoria de Gestão Estratégica do Supremo Tribunal Federal, indicando que no período citado foram proferidas 25.707 decisões de mérito proferidas em recursos criminais pelo STF (Recursos Extraordinários e Agravos).
} 
por Neil MacCormick.

\begin{tabular}{|c|c|c|}
\hline \multicolumn{3}{|r|}{ Tabela 3} \\
\hline \multicolumn{3}{|r|}{ Ministro Luís Roberto Barroso } \\
\hline Decisão & Conhe & $\begin{array}{l}\text { eu e denegou a ordem autorizando a execução da pena após a decisão condenatória } \\
\text { de segundo grau. }\end{array}$ \\
\hline $\begin{array}{l}\text { Páginas do } \\
\text { Acórdão }\end{array}$ & & 27 a 54 \\
\hline $\begin{array}{l}\text { Argumentos } \\
\text { Lingüísticos }\end{array}$ & & $\begin{array}{l}\text { O princípio da presunção de inocência está definido no texto constitucional no } \\
\text { art. } 5^{\circ} \text {, LVII da Constituição Federal e indica que "ninguém será considerado } \\
\text { culpado até o trânsito em julgado de sentença penal condenatória"; } \\
\text { a lei não autoriza a aplicação de efeitos suspensivos nos Recursos Especial e } \\
\text { Extraordinário; } \\
\text { art. } 5^{\circ} \text {, LXI da Constituição Federal que dispõe que o pressuposto para a prisão no } \\
\text { sistema constitucional brasileiro, é a ordem escrita e fundamentada de autoridade } \\
\text { judiciária competente; } \\
\text { art. } 5^{\circ} \text {, capute Art. } 144 \text { (segurança pública), ambos da Constituição Federal. }\end{array}$ \\
\hline $\begin{array}{l}\text { Argumentos } \\
\text { Sistêmicos }\end{array}$ & c) & $\begin{array}{l}\text { Indica que o direito não existe de forma abstrata, fora da realidade na qual está } \\
\text { inserido, indicando que o mesmo deve ser aplicado de forma relacionada à } \\
\text { realidade dos fatos da sua época (exemplo de argumento histórico); } \\
\text { mostra que em } 2009 \text { houve uma mutação constitucional inicial sobre a matéria no } \\
\text { julgamento da ação de habeas corpus no } 84.078 \text { /MG e que agora deve haver outra } \\
\text { em nome de uma necessidade de perceber "o impacto traumático da própria } \\
\text { realidade que se criou após a primeira mudança de orientação"; } \\
\text { enumera três consequências advindas ou reforçadas com a adoção do } \\
\text { entendimento anterior que produziram efeitos reais e que levam a conclusão de } \\
\text { que a decisão passada (do HC no } 84.078 / \text { MG) confronta-se com a lógica da } \\
\text { realidade, são elas: ter funcionado a decisão como um "poderoso incentivo à } \\
\text { infindável interposição de recursos protelatórios", reforçou "a seletividade do } \\
\text { sistema penal" já que "a possibilidade de recorrer em liberdade aproveita } \\
\text { sobretudo aos réus abastados", e por fim, contribuir "para agravar o descrédito do } \\
\text { sistema de justiça penal junto à sociedade"; } \\
\text { interpretando-se sistematicamente o texto constitucional deve-se perceber que, } \\
\text { enquanto o princípio da presunção do estado de inocência fala que "ninguém será } \\
\text { considerado culpado", quando se percebe as exigências constitucionais sobre os } \\
\text { requisitos de prisão, o indicado na Constituição é que "ninguém será preso senão } \\
\text { em flagrante delito ou por ordem escrita e fundamentada de autoridade judiciária } \\
\text { competente", ou seja, fácil perceber que são utilizadas expressões distintas; } \\
\text { em seu pensamento, a Constituição "é um conjunto orgânico e integrado de } \\
\text { normas, que devem ser interpretadas sistematicamente na sua conexão com todas } \\
\text { as demais, e não de forma isolada"; } \\
\text { o princípio da presunção de inocência é um princípio e, portanto, expressa } \\
\text { "valores a serem preservados ou fins públicos a serem realizados"; desta forma há } \\
\text { maior liberdade da interpretação e aplicação de um princípio do que de uma regra, } \\
\text { ou seja, "não se aplicarem na base do tudo ou nada" e, em havendo o conflito de } \\
\text { princípios, deve-se utilizar a técnica da ponderação; }\end{array}$ \\
\hline
\end{tabular}




\begin{tabular}{|c|c|c|}
\hline & $\begin{array}{l}\text { g) } \\
\text { h) }\end{array}$ & $\begin{array}{l}\text { entende o magistrado que no caso concreto há um conflito entre dois grupos de } \\
\text { normas constitucionais. De um lado o princípio da presunção de inocência, do } \\
\text { outro o "interesse constitucional na efetividade da lei penal, em prol dos objetivos } \\
\text { e bens jurídicos"; } \\
\text { "o princípio da presunção de inocência ou da não culpabilidade adquire peso } \\
\text { gradativamente menor na medida em que o processo avança, em que as provas } \\
\text { são produzidas e as condenaçães ocorrem", assim considerando a ponderação de } \\
\text { princípios diante do conflito instaurado; à medida que o processo avança o } \\
\text { princípio da efetividade da lei penal ganha maior relevância pois passa o feito penal } \\
\text { a ser dotado de maior grau de certeza no que tange a responsabilização criminal; } \\
\text { o princípio da proporcionalidade possui uma dimensão positiva que se refere à } \\
\text { "vedação à proteção estatal insuficiente de direitos e princípios constitucionais } \\
\text { tutelados" e diante disso deve haver restrições à aplicação do princípio da } \\
\text { presunção de inocência especialmente após a decisão do juízo de primeiro grau e } \\
\text { dos tribunais de apelação; } \\
\text { o magistrado aponta argumentos de índole infraconstitucional como, por } \\
\text { exemplo, o de que a prisão muitas vezes é necessária para a garantia da ordem } \\
\text { pública e nesse sentido a demora na aplicação da pena, na efetivação da sanção } \\
\text { criminal acaba por comprometer a ordem pública; } \\
\text { outro argumento utilizado como fundamentador da decisão é o abuso no direito } \\
\text { de defesa, muitas vezes caracterizado pelo uso excessivo de recursos e que muitas } \\
\text { vezes acaba por retardar a decisão judicial. }\end{array}$ \\
\hline $\begin{array}{l}\text { Argumentos } \\
\text { Teleológicos- } \\
\text { Deontológicos }\end{array}$ & a) & $\begin{array}{l}\text { A busca por uma maior eficiência do processo penal, diminuição da seletiva no } \\
\text { sistema de justiça criminal são objetivos da Constituição Federal especialmente } \\
\text { quando ele dispõe sobre celeridade processual e direito à vida, integridade física, } \\
\text { segurança, dentre outros. }\end{array}$ \\
\hline
\end{tabular}

\section{Voto da Ministra Rosa Weber}

O voto da Ministra Rosa Weber constitui um dos mais sintéticos e resumidos a comporem o acórdão. Ele inaugura formalmente a divergência já que os magistrados anteriores, mesmo usando argumentos distintos, votaram na mesma direção. O principal argumento fundamentador da decisão da Ministra foi o de preservação da jurisprudência da corte, ou seja, a manutenção dos precedentes.

\begin{tabular}{|c|c|c|}
\hline \multicolumn{3}{|r|}{ Tabela 4} \\
\hline \multicolumn{3}{|r|}{ Ministra Rosa Weber } \\
\hline Decisão & & Conheceu e concedeu a ordem. \\
\hline $\begin{array}{l}\text { Páginas do } \\
\text { Acórdão }\end{array}$ & & 55 a 57 \\
\hline $\begin{array}{l}\text { Argumentos } \\
\text { Sistêmicos }\end{array}$ & & $\begin{array}{l}\text { A manutenção da jurisprudência do STF foi o que orientou o voto da Ministra, } \\
\text { tendo ela indicado esse como fundamento maior de sua decisão (exemplo de } \\
\text { argumento do precedente); } \\
\text { a revisão da jurisprudência não se deve dar apenas por mudança da composição do }\end{array}$ \\
\hline
\end{tabular}


tribunal já que isso pode comprometer a segurança jurídica das decisões.

\section{Voto do Ministro Luiz Fux}

O voto do Ministro Luiz Fux adere ao voto do Ministro relator e consequentemente conhece e denega a ordem. Trata-se de um voto sucinto, porém a desenvolver argumentos complementares aos demais, buscando especialmente argumentos históricos e no direito comparado.

\begin{tabular}{|c|c|}
\hline \multicolumn{2}{|r|}{ Tabela 5} \\
\hline \multicolumn{2}{|r|}{ Ministro Luiz Fux } \\
\hline Decisão & $\begin{array}{l}\text { Conheceu e denegou a ordem, autorizando a execução da pena após a decisão condenatória de } \\
\text { segundo grau. }\end{array}$ \\
\hline $\begin{array}{l}\text { Páginas do } \\
\text { Acórdão }\end{array}$ & 58 a 60 \\
\hline $\begin{array}{l}\text { Argumentos } \\
\text { Lingüísticos }\end{array}$ & $\begin{array}{l}\text { a) Declaração dos Direitos Humanos da Organização das Nações Unidas que dispõe } \\
\text { que "toda pessoa acusada de um ato delituoso tem o direito de ser presumida inocente } \\
\text { até que a sua culpabilidade tenha sido provada"; } \\
\text { b) o princípio da presunção de inocência está definido no texto constitucional no art. 5', } \\
\text { LVII da Constituição Federal e indica que "ninguém será considerado culpado até o } \\
\text { trânsito em julgado de sentença penal condenatória". }\end{array}$ \\
\hline $\begin{array}{l}\text { Argumentos } \\
\text { Sistêmicos }\end{array}$ & $\begin{array}{l}\text { a) Indica como argumento não principal a idéia de que o princípio da presunção de } \\
\text { inocência tem origens históricas, ligadas a ideia de que uma pessoa é considerada } \\
\text { inocente até que se prove sua culpa; (exemplo de argumento histórico); } \\
\text { b) a admissão pelo STF da coisa julgada em capítulos representa mais um elemento que } \\
\text { faz com que não exista impedimento para a execução imediata da pena após a decisão } \\
\text { condenatória de segundo grau; } \\
\text { c) a impossibilidade de aplicação imediata da pena após a decisão condenatória ou } \\
\text { confirmatória da condenação pelos tribunais de apelação pode levar a situações } \\
\text { incongruentes, como aquela de a execução não ocorrer por ingerência da defesa ou } \\
\text { mesmo a ocorrência da prescrição; } \\
\text { d) "é fundamental o abandono dos precedentes em virtude da incongruência sistema ou } \\
\text { social", e diante disso é fundamental que deixe de ser aplicado um precedente que não } \\
\text { mais corresponde à realidade jurídica ou mesmo já não está mais em harmonia com o } \\
\text { texto constitucional ou sua melhor interpretação. }\end{array}$ \\
\hline
\end{tabular}

\section{Voto da Ministra Carmen Lúcia}

O voto da Ministra Carmen Lúcia inicia deixando claro qual o seu entendimento sobre a matéria e principalmente indicando que em outras ocasiões, adotando o entendimento do Ministro relator restou vencida, especialmente no julgamento da ação de habeas corpus de 2009, que alterou o entendimento do STF sobre a 
matéria. A Ministra entende que, exaurida a fase de produção e apreciação da prova (que ocorre após o julgamento pelo juízo de segundo grau), não existe óbice para a aplicação imediata que pena. Desta forma adere ao voto condutor do Ministro-relator.

\begin{tabular}{|c|c|}
\hline \multicolumn{2}{|r|}{ Tabela 6} \\
\hline \multicolumn{2}{|r|}{ Ministra Cármen Lúcia } \\
\hline Decisão & $\begin{array}{c}\text { Conheceu e denegou a ordem autorizando a execução da pena após a decisão condenatória de } \\
\text { segundo grau. }\end{array}$ \\
\hline $\begin{array}{l}\text { Páginas do } \\
\text { Acórdão }\end{array}$ & 61 a 62 \\
\hline $\begin{array}{l}\text { Argumentos } \\
\text { Lingüísticos }\end{array}$ & $\begin{array}{l}\text { a) O princípio da presunção de inocência está definido no texto constitucional no art. } \\
5^{\circ} \text {, LVII da Constituição Federal e indica que "ninguém será considerado culpado até } \\
\text { o trânsito em julgado de sentença penal condenatória". }\end{array}$ \\
\hline $\begin{array}{c}\text { Argumentos } \\
\text { Sistêmicos }\end{array}$ & $\begin{array}{l}\text { a) O exaurimento da análise da prova e consequentemente construção da conviçcão } \\
\text { fática do julgador ocorre com a conclusão do julgamento pelo juízo de segundo grau, } \\
\text { com isso não existe impedimento para a aplicação provisória de pena. } \\
\text { b) "A Constituição determina é a não culpa definitiva antes do trânsito, e não a não } \\
\text { condenação"; (exemplo de argumento de harmonização contextual). }\end{array}$ \\
\hline
\end{tabular}

\section{Voto do Ministro Gilmar Mendes}

O Ministro inicia o voto lembrando as condições e termos da decisão do Supremo Tribunal do habeas corpus 84.078/MG e que estabeleceu o entendimento vigente até esse ano de necessidade do trânsito em julgado para execução da pena, dando especial destaque ao voto na época do Ministro Cezar Peluso. Adere ao voto do Ministro relator, fazendo algumas complementações especialmente indicando elementos de direito comparado.

A síntese conceitual do voto do Ministro, que entende como a maioria de que deve a pena ser aplicada logo, é que "esgotadas as instâncias ordinárias com a condenação à pena privativa de liberdade não substituída, tem-se uma declaração, com considerável força de que o réu é culpado e a sua prisão necessária."

Destaca ainda que no direito comparado é a declaração de culpa, com a conclusão da fase probatória que exaure a presunção e não o trânsito em julgado da decisão condenatória.

\begin{tabular}{|c|c|}
\hline \multicolumn{2}{|r|}{ Tabela 7} \\
\hline \multicolumn{2}{|r|}{ Ministro Gilmar Mendes } \\
\hline Decisão & $\begin{array}{c}\text { Conheceu e denegou a ordem autorizando a execução da pena após a decisão condenatória de } \\
\text { segundo grau. }\end{array}$ \\
\hline $\begin{array}{l}\text { Páginas do } \\
\text { Acórdão }\end{array}$ & 63 a 75 \\
\hline Argumentos & a) O princípio da presunção de inocência está definido no texto constitucional no art. $5^{\circ}$, \\
\hline
\end{tabular}




\begin{tabular}{|c|c|c|}
\hline Lingüísticos & b) & $\begin{array}{l}\text { LVII da Constituição Federal e indica que "ninguém será considerado culpado até o } \\
\text { trânsito em julgado de sentença penal condenatória"; } \\
\text { o art. } 637 \text { do Código de Processo Penal não confere efeito suspensivo aos recursos } \\
\text { especial e extraordinário; } \\
\text { art. 1', I, "e" da Lei Complementar 64/90 introduzido pela Lei Complementar 135/10 } \\
\text { (Lei da Ficha Limpa). }\end{array}$ \\
\hline $\begin{array}{c}\text { Argumentos } \\
\text { Sistêmicos }\end{array}$ & a) & $\begin{array}{l}\text { O excesso de prisões provisórias no Brasil e consequentemente a demora na execução } \\
\text { da pena é um dos argumentos apontados como fundamentadores da decisão que } \\
\text { autoriza a execução penal já após a decisão de segundo grau; } \\
\text { considerando que a presunção de inocência é um princípio e não uma regra, "é natural } \\
\text { à presunção de não culpabilidade evoluir de acordo com o estágio do procedimento. } \\
\text { Desde que não atinja o núcleo fundamental, o tratamento progressivamente mais } \\
\text { gravoso é aceitável"; } \\
\text { "esgotadas as instâncias ordinárias com a condenação à pena privativa de liberdade não } \\
\text { substituída, tem-se uma declaração, com considerável força de que o réu é culpado e a } \\
\text { sua prisão necessária”; } \\
\text { indica que no direito comparado está longe de ser a regra a impossibilidade de } \\
\text { aplicação de pena tão logo se tenha uma decisão condenatória de primeiro ou segundo } \\
\text { graus já que "todas escolhem, como marco para a cessação da presunção, o momento } \\
\text { em que a culpa é provada de acordo com o direito. Resta saber em que momento isso } \\
\text { ocorre”; } \\
\text { "o que eu estou colocando, portanto, para nossa reflexão é que é preciso que vejamos a } \\
\text { presunção de inocência como um princípio relevantíssimo a para ordem pública ou } \\
\text { constitucional, mas princípio suscetível de ser devidamente conformado, tendo em } \\
\text { vista, inclusive, as circunstâncias de aplicação no caso do Direito Penal e Processual } \\
\text { Penal. Por isso, eu entendo que, nesse contexto, não é de se considerar que a prisão, } \\
\text { após a decisão do tribunal de apelação, haja de ser considerada violadora desse } \\
\text { princípio." }\end{array}$ \\
\hline
\end{tabular}

\section{Voto do Ministro Marco Aurélio}

O voto do ministro Marco Aurélio diverge do voto do Ministro relator, mantendo com isso a mesma linha decisória que já tinha adotado quando do julgamento do habeas corpus nº 84.078/MG em 2009.

A exemplo do que fez a Ministra Rosa Weber, a preservação do entendimento da Corte Suprema e manutenção da jurisprudência do STF foram apresentados como elementos essenciais para a decisão.

\begin{tabular}{|c|c|c|}
\hline \multicolumn{3}{|r|}{ Tabela 8} \\
\hline \multicolumn{3}{|r|}{ Ministro Marco Aurélio } \\
\hline Decisão & & Conheceu e concedeu a ordem. \\
\hline $\begin{array}{l}\text { Páginas do } \\
\text { Acórdão }\end{array}$ & & 76 a 79 \\
\hline $\begin{array}{l}\text { Argumentos } \\
\text { Lingüísticos }\end{array}$ & & $\begin{array}{l}\text { O princípio da presunção de inocência está definido no texto constitucional no } \\
\text { art. } 5^{\circ} \text {, LVII da Constituição Federal e indica que "ninguém será considerado }\end{array}$ \\
\hline
\end{tabular}




\begin{tabular}{|c|c|c|}
\hline & & culpado até o trânsito em julgado de sentença penal condenatória"; \\
\hline $\begin{array}{l}\text { Argumentos } \\
\text { Sistêmicos }\end{array}$ & a) & $\begin{array}{l}\text { A preservação da jurisprudência da Corte Superior, para evitar mudanças } \\
\text { pontuais ou casuísticas é um dos argumentos apresentados pelo julgador para } \\
\text { conceder a ordem e manter o mesmo entendimento adotado em } 2009 \text { que ele } \\
\text { chega a chamar de "recente"; (exemplo de argumentos do precedente); } \\
\text { indica que o texto constitucional que define o princípio da presunção de } \\
\text { inocência é claro e não dá margem a interpretações, especialmente que venham a } \\
\text { mudar o sentido conferido pelo legislador constituinte, afirmando que "há uma } \\
\text { máxima, em termos de noção de interpretação, de hermenêutica, segundo a qual } \\
\text { onde o texto é claro e preciso, cessa a interpretação, sob pena de se reescrever a } \\
\text { norma jurídica, e, no caso, o preceito constitucional." }\end{array}$ \\
\hline $\begin{array}{l}\text { Argumentos } \\
\text { Teleológicos- } \\
\text { Deontológicos }\end{array}$ & a) & $\begin{array}{l}\text { O Poder Judiciário não pode avançar, ir além de seus limites, especialmente } \\
\text { conferindo ao texto constitucional significado diverso daquele dado pelo } \\
\text { constituinte já que a finalidade institucional do Poder não é essa. }\end{array}$ \\
\hline
\end{tabular}

\section{Voto do Ministro Celso de Mello}

O Ministro Celso de Mello igualmente manteve o entendimento que havia adotado no julgamento do 2009, indicando que entende que não deve haver flexibilizações na aplicação do princípio da presunção de inocência, especialmente considerando tratar-se de garantia constitucional. Com isso, somente após o trânsito em julgado é possível a aplicação da pena respectiva.

Em seu voto, utiliza argumentos relacionados ao caráter absoluto da presunção de inocência, especialmente considerando que não se deve tolerar qualquer relativização do mesmo já que represente uma garantia face do poder estatal. Utiliza de fundamentos constitucionais, doutrinários e legais porém sempre reforçando o mesmo argumento do caráter absoluto da garantia.

\begin{tabular}{|c|c|c|}
\hline \multicolumn{2}{|c|}{$\begin{array}{c}\text { Tabela } 9 \\
\text { Ministro Celso de Mello } \\
\text { Conheceu e concedeu a ordem. }\end{array}$} \\
\hline $\begin{array}{c}\text { Decisão } \\
80 \text { a } 96\end{array}$ \\
\hline $\begin{array}{c}\text { Páginas do Acórdão } \\
\text { Lingumentos }\end{array}$ & a) & \multicolumn{1}{|c|}{$\begin{array}{c}\text { O princípio da presunção de inocência está definido no texto constitucional no } \\
\text { art. } 5^{\circ}, \text { LVII da Constituição Federal e indica que "ninguém será considerado } \\
\text { culpado até o trânsito em julgado de sentença penal condenatória"; }\end{array}$} \\
\hline $\begin{array}{c}\text { Argumentos } \\
\text { Sistêmicos }\end{array}$ & a) $\begin{array}{l}\text { a presunção de inocência historicamente representa uma grande conquista do } \\
\text { acusado em face da atuação do poder estatal; (argumento histórico); } \\
\text { indica dispositivos de direito comparado, bem como de convenções e tratados } \\
\text { internacionais que reforçam o caráter absoluto do princípio da presunção de } \\
\text { inocência o que impede a aplicação da pena antes desse momento; }\end{array}$ \\
\hline
\end{tabular}




\begin{tabular}{|c|c|c|}
\hline c) & $\begin{array}{l}\text { a proteção do individuo face a atuação estatal e valorização de seus direitos e } \\
\text { garantias representa elemento central na construção do entendimento }\end{array}$ \\
& $\begin{array}{l}\text { jurisprudencial adotado pelo STF, desta forma, qualquer interpretação em } \\
\text { sentido contrário ou tendente a limitar direitos e garantias não deve ser admitida; } \\
\text { (exemplo do argumento do precedente) }\end{array}$ \\
\hline Argumentos & a) & $\begin{array}{l}\text { utiliza algumas vezes como argumento a idéia de que o STF deve ter em mente } \\
\text { que sua função essencial é a garantia da supremacia da Constituição e que as } \\
\text { Teleológicos- } \\
\text { Deontológicos } \\
\text { decião devem ser tomadas com base no objetivo indicado pelo legislador } \\
\text { constuante, qual seja, a maior e mais ampla proteção do indivíduo em face da } \\
\text { atualal. }\end{array}$ \\
\hline
\end{tabular}

\section{Voto do Ministro Ricardo Lewandowski}

O Presidente do STF também manteve o entendimento já declarado quando do julgamento de 2009, a compreender que a ordem deveria ser conhecida e concedida, especialmente por não visualizar possibilidade de relativização do disposto expressamente no texto constitucional. $\mathrm{O}$ argumento principal utilizado é que o dispositivo que define o princípio é claro o suficiente e confere uma única possibilidade de interpretação.

\begin{tabular}{|c|c|c|}
\hline \multicolumn{3}{|r|}{ Tabela 10} \\
\hline \multicolumn{3}{|r|}{ Ministro Ricardo Lewandowski } \\
\hline Decisão & & Conheceu e concedeu a ordem. \\
\hline $\begin{array}{l}\text { Páginas do } \\
\text { Acórdão }\end{array}$ & & 97 a 102 \\
\hline $\begin{array}{l}\text { Argumentos } \\
\text { Lingüísticos }\end{array}$ & & $\begin{array}{l}\text { O princípio da presunção de inocência está definido no texto constitucional no art. 5o, } \\
\text { LVII da Constituição Federal e indica que "ninguém será considerado culpado até o } \\
\text { trânsito em julgado de sentença penal condenatória". }\end{array}$ \\
\hline $\begin{array}{c}\text { Argumentos } \\
\text { Sistêmicos }\end{array}$ & & $\begin{array}{l}\text { Indica como fundamento de sua decisão a impossibilidade de interpretação do } \\
\text { dispositivo constitucional já que o mesmo é claro o suficiente para que dele se pode } \\
\text { extrair o entendimento pleno e único; } \\
\text { a interposição de recurso especial ou extraordinário faz com que se obste a execução } \\
\text { de pena considerando que ainda não é possível falar em culpa ou condenação } \\
\text { definitiva, ou seja, ainda milita em favor do réu a presunção de inocência; } \\
\text { a situação crítica do sistema penitenciário brasileiro é tomada como argumento, } \\
\text { indicando que permitir a execução de pena antes do trânsito em julgado da decisão } \\
\text { condenatória representa incremento indevido no número de presos no sistema } \\
\text { prisional, o que compromete ainda mais a situação já crítica. }\end{array}$ \\
\hline
\end{tabular}




\section{ANÁLISE DO ACORDÃO NOS TERMOS DA TEORIA DE NEIL MACCORMICK ESPECIALMENTE NO QUE TANGE A UNIVERSALIDADE, COERÊNCIA E CONSISTÊNCIA}

Após a análise dos votos dos ministros que compõem o acórdão do habeas corpus nº 126.292/SP é relevante definir, considerando os termos da teoria de Neil MacCormick, que, por um lado, a decisão como um todo é dotada de universalidade, coerência e consistência razoáveis. Tais requisitos são fundamentais para que se possa declarar que a decisão válida e dotada de plena eficácia. Por outro lado, a utilização dos argumentos mostrados por MacCormick, no que pese seu reconhecido esforço teórico, pode servir a dois parâmetros absolutamente distintos, como se verá.

Inicialmente é relevante conceituar cada um dos requisitos para empós analisar no caso concreto a existência ou não dos mesmos. Como afirma Ana Maria D`Ávila Lopes e Márcio Benício (2015, p. 50) "o requisito da universalidade, fundado nos princípios de igualdade e segurança jurídica, exige que os argumentos da decisão possam ser aplicados a casos semelhantes". Uma decisão universal é aquela que deve ser aplicada a casos semelhantes. A idéia fundamental do requisito é que ao julgar um determinado caso, o julgador deve estruturar a decisão de forma que possa ser utilizada em outras situações que possuem ou guardem as mesmas condições e características. Desta forma ao julgar deve-se pensar nas conseqüências e no alcance da decisão.

O requisito da consistência indica que a decisão ao ser tomada deve guardar uma conexão interna de seus argumentos para que o conjunto de elementos que levaram ao mandamento judicial. A existência dessa uniformidade e complementação dos elementos que levaram o julgador a decidir representam que a mesma é mais consistente, logo mais eficaz e válida. É "definido como a não contradição de uma norma com seus próprios fundamentos" (LOPES; BENÍCIO, 2015, p. 50).

A conexão entre os termos e argumentos da decisão judicial e os fundamentos jurídicos presentes no ordenamento e sistema legal e constitucional representam o que se deve compreender como o requisito de coerência. $\mathrm{O}$ mandamento judicial coerente "implica a coesão lógica entre os argumentos utilizados na decisão e o sistema jurídico como um todo." (LOPES; BENÍCIO, 2015. p. 50).

A seguir, passa-se a análise da decisão quando a existência ou não de tais requisitos, e consequentemente a existência de tais requisitos.

\section{Da Universalidade}

Analisando os termos da decisão, especialmente os argumentos específicos dos votos dos ministros, parece evidente que a decisão atende ao requisito da universalidade já que a matéria tratada pode ser largamente aplicada vol.11, no. 03, Rio de Janeiro, 2018.pp. 1704-1733 
em outros casos. Na verdade, a análise e principalmente a matéria tratada indiscutivelmente possui alcance geral. Prova maior disso é o trecho do voto do Ministro relator, onde ele declara de forma expressa que entendia necessário a superação da súmula no 691 do próprio STF e pela qual não se pode conhecer ação de habeas corpus impetrada contra decisão de relator que indeferiu medida liminar.

Ao indicar que, por ser contrária ao entendimento até então dominante na jurisprudência do STF, a decisão atacada possuía característica excepcional que admitia o conhecimento da matéria. Ademais, indica que por ser a matéria em comento relevante e de alcance geral era necessário o conhecimento da ação e deliberação sobre o alcance do princípio da presunção de inocência, que em outras palavras é a discussão de fundo do writ.

Como se disse, a uma primeira vista o requisito da universalidade parece ser evidente. Ocorre que há dois aspectos a merecerem registro crítico: a) após esta decisão, já se discute, no âmbito do STF, o retorno do entendimento de 2009; qual seja, àquele de que a constitucional presunção de inocência implica na impossibilidade de réu preso antes do trânsito em julgado da decisão; b) os votos vencidos, que parecem ter recebido novo fôlego na discussão jurisprudencial, também indicam com clareza seus pressupostos constitucionais de validade, extensivos a todos e de alcance geral.

A pergunta que emerge é: a sólida teorização de MacCormick aplica-se ao caso brasileiro, ou ainda estamos diante de uma "insubsistência jurisprudencial", diante de instantes tão acirrados na democracia constitucional brasileira? Este aspecto, por óbvio, não é enfrentado por MacCormick - donde não lhe pode ser imputada responsabilidade alguma - e cabe ao cientista brasileiro o descortinar de tal quadro institucional e político.

\section{Da Consistência}

O requisito da consistência representa a adequação interna da decisão, ou seja, que seus termos próprios e íntimos tenham uma lógica própria que faça com que os argumentos, quando analisados em conjunto, possam dar a decisão uma unidade capaz de dar a mesma a eficiência, validade e legitimidade esperados. Os argumentos funcionam como músicos de uma orquestra que uma vez tocando em harmonia produzem um único som. No caso de um mandamento judicial, ao "ouvir vários sons" emanados, tem-se que a mesma não possui plena consistência.

No caso do julgamento ora analisado, é possível concluir que o acórdão não satisfaz tal requisito. Em parte, explica-se pela contradição existente, uma vez que o julgamento final se deu por maioria, e não por unanimidade (como visto acima foi por sete votos a quatro). Tal fato por si só justifica a inexistência do requisito.

Outro elemento que se pode destacar é que os ministro muitas vezes utilizam analisam o mesmo ponto 
(como exemplo se pode considerar o conceito próprio do princípio da presunção de inocência) conferindo significados distintos. Assim, partem do mesmo tipo de argumento lingüístico para depois complementarem com outros argumentos, notadamente sistêmicos, e com isso divergir significativamente.

O Ministro Ricardo Lewandowski indica como um dos seus fundamentos a idéia de que sequer consegue visualizar margem interpretativa no dispositivo constitucional que define o princípio da não culpabilidade, daí porque não enxergar possibilidade de relativização do mesmo.

Já os Ministros Edson Fachin, Luis Roberto Barroso e Teori Zavascki não apenas o interpretam, como extraem do dispositivo um significado não apenas não absoluto, mas que permite visualizar compatibilização do mesmo com a aplicação imediata da pena. Em outras palavras, o STF atingiu dois pontos absolutamente opostos a partir de idêntico dispositivo constitucional.

Outro ponto onde se pode visualizar um conflito no uso dos argumentos, o que compromete a existência da consistência, é a relevância teórica que é dada a possibilidade de reversão da decisão em favor do réu com o julgamento dos recursos especiais e extraordinários. O Ministro Luís Barroso mostra que, citando dados estatísticos do próprio tribunal, que apenas cerca de $1 \%$ (um por cento) dos recursos extraordinários julgados entre os anos de 2009 e 2016 foram decididos a favor da defesa e alteraram a decisão original, sendo a maioria versando apenas sobre o regime prisional. Outros ministros (Ministro Celso de Mello, por exemplo) indica que a possibilidade de mudança do julgamento com benefício para o réu por si já autoriza a não aplicação da execução provisória penal.

Desta forma, resta evidente que o requisito da consistência não pode ser tido como plenamente existente no acórdão.

\section{Da Coerência}

Atender ao requisito da coerência significa que os argumentos que levaram a decisão guardam harmonia e conexão com aqueles existentes no ordenamento jurídico. Nesse caso, igualmente verifica-se que o acórdão analisado não atende plenamente a esse requisito, especialmente considerando que alguns dispositivos legais e constitucionais são constantemente invocados como fundamentos, porém recebem interpretação bem distinta pelos julgadores.

Como exemplo é possível citar a interpretação dada ao art. 637 do Código de Processo Penal que indica que os recursos especiais e extraordinários não serão dotados de efeito suspensivo. Alguns ministros, especialmente os que denegaram a ordem pretendida como o Ministro Luis Barroso, indicam que a existência de tal dispositivo é um dos argumentos e fundamentos que autorizam a execução imediata da pena uma vez 
superadas as instâncias ordinárias e, portanto, exaurida a questão relativa à produção e valoração da prova, não haveria impedimento jurídico para isso.

Por outro lado, sinaliza o Ministro Marco Aurélio que a interpretação de um dispositivo legal deve ser feita com base e em harmonia com o disposto na Constituição Federal. Assim, o disposto no art. 637 do Código de Processo Penal não pode ser aplicado de forma a limitar ou diminuir o alcance do princípio da presunção de inocência, que tem sede na Constituição da República.

Verifica-se assim que, considerando o conflito entre os votos (que produziu uma decisão por maioria) tem-se uma decisão não plenamente coerente quando se considera os argumentos nela empregados e a respectiva compatibilidade com o ordenamento jurídico aplicável.

\section{CONCLUSÃO}

A decisão que julgou a ação de habeas corpus 126.292/SP obrigou o STF a novamente discutir os limites e alcances do princípio da presunção de inocência, especialmente considerando a possibilidade ou não de aplicação imediata de pena após a decisão condenatória ou confirmatória da decisão pelo juízo de segundo grau, ou seja, Tribunais de Justiça ou Tribunais Regionais Federais, por exemplo.

No julgamento, o STF mudou o entendimento adotado por ela em 2009 (no habeas corpus 84.078/MG) e que entendeu que o citado princípio deveria ser visto como absoluto. Esta decisão por sua vez representou mudança na formação da jurisprudência do tribunal, já que desde a edição da Constituição Federal de 1988 admitia-se a aplicação provisória da pena. Verifica-se com isso que a decisão tomada em 2016 representa a volta ao entendimento já adotado no passado, renovando-se com isso a formação da jurisprudência.

O presente trabalho analisou tal decisão ( $\left.\mathrm{HC} \mathrm{n}^{\circ} 126.292 / \mathrm{SP}\right)$ com base na teoria de interpretação e argumentado de Neil MacCormick que indica que, tomando como base os argumentos utilizados no julgado (linguísticos, sistêmicos ou deontológicos/teleológicos) é possível definir se a sentença ou acórdão são dotados de universalidade, coerência ou consistência suficientes para conferir a validade e eficácia necessárias.

No caso da decisão em análise é possível concluir que o acórdão pode ser tido, com reservas, como universal, porém não coerente e consistente, ou seja, a matéria e a conclusão do julgamento podem ser utilizadas em outros casos, porém há fortes conflitos internos, quer no que tange aos argumentos em si, quer na compatibilidade desses com o ordenamento jurídico, que fazem com que o mesmo perca coerência e consistência.

Em parte, isto é explicado pelo julgamento feito por maioria, em parte por ter existirem visões e interpretações bem conflitantes entre os ministros que compõe o STF. Por fim, não se pode olvidar, que o STF, 
em momentos de crise institucional e bpolítica, como a que vive o Brasil desde 2015 até o momento em que se finaliza este texto (janeiro de 2018), parece não ter sido capaz de dar respostas de estabilidade tão necessária à Constituição Federal.

\title{
THE TRIAL OF HABEAS CORPUS 126.292 / SP THE SUPREME FEDERAL COURT FROM THE PERSPECTIVE OF NEIL MACCORMICK THINKING ABOUT ARGUMENT OF JUDICIAL DECISION
}

\begin{abstract}
The article analyzes the trial of the action of habeas corpus 126.292 / SP by the Supreme Court, occurred on February 17, 2016, in which, from the examination of the concept and limits of the principle of the state of innocence presumption, it is now admitted the execution of the penalty after the confirmatory decision about the conviction pronounced by the second degree Court. The present study takes as reference the theory of argumentation by Neil MacCormick, especially considering that the judgment meets the essential elements to be contained in a judicial decision, which are consistency, coherence and universality. Initially, it is lectured about the concept of the principle of presumption of innocence and its legal nature. The second topic of the article seeks to summarize the content of the decision under study, to then analyze the arguments contained in the votes of ministers, to then review the terms of the judgment from the perspective of the proposed by Neil MacCormick. It is concluded that the decision attends to the universality required, but does not fulfill the requisites of coherence and consistency, especially considering it was taken by a majority vote and with the analysis of the arguments contained therein. The methodology used is literature, doctrinal, legislative and jurisprudential.
\end{abstract}

Keywords: Presumption of innocence; Execution Penalty; Criminal conviction.

\section{REFERENCIAS}

BRASIL. Código de Processo Penal. Disponível em: <www.planalto.gov.br/codi>. Acesso em: 17 mar. 2018.

Constituição (1988). Constituição da República Federativa do Brasil. Brasília, DF, Senado, 1988. Disponível em: <www.planalto.gov.br/constituicao/constituicao.htm. Acesso em: 17 mar. 2018.

Decreto Legislativo $\mathrm{n}^{\circ}$ 678, de 06 de novembro de 1992. Disponível em: $<$ http://www.planalto.gov.br/ccivil_03/decreto/d0678.htm?TSPD_101_R0=187bfcfd96f963572629cc59153 $28 c 75 z 0 i 000000000000000087 \mathrm{dcddb} 5 \mathrm{ffff} 00000000000000000000000000005 \mathrm{aad} 1 \mathrm{f} 7800 \mathrm{be} 3 \mathrm{a} 3 \mathrm{e} 88>$. Acesso em: 17 mar. 2018.

Supremo Tribunal Federal - STF. Ação de Habeas Corpus: HC 84.078/MG. Relator: Ministro Eros Grau. Diário de Justiça, Brasília, DF, 5 fev. 2009. Disponível em: $<$ http://www.stf.jus.br/arquivo/cms/noticiaNoticia-Stf/anexo/ementa84078.pdf>. Acesso em: 18 jan. 2018.

Supremo Tribunal Federal - STF. Ação de Habeas Corpus: HC 126.292/SP. Relator: Ministro Teori Zavascki. Diário de Justiça, Brasília, DF, 17 fev. 2016. Disponível em: <http:// www.stf.jus.br/arquivo/cms/noticiaNoticiaStf/anexo/ementa84078.pdf> Acesso em: 18 jan. 2018.

Supremo Tribunal Federal - STF. Ação de Habeas Corpus: HC 84.078/MG. Relator: Ministro Eros 
Grau. Diário de Justiça, Brasília, DF, 5 fev. 2009. Disponível em <http:// www.stf.jus.br/arquivo/cms/noticiaNoticiaStf/anexo/ementa84078.pdf>. Acesso em: 18 jan. 2018.

CATENA, Victor Morena. Sobre o princípio da presunção de inocência. Revista do Centro de Estudos Judiciários - Conselho da Justiça Federal, Brasília, n. 67, p. 101-111, 2015.

CONVENÇÃO EUROPÉIA DOS DIREITOS HUMANOS. Disponível em: <https://www.echr.coe.int/Documents/Convention_POR.pdf>. Acesso em: 17 mar. 2018.

DECLARAÇÃO DOS DIREITOS DO HOMEM E DO CIDADÃO. Disponível em: $<$ http://pfdc.pgr.mpf.mp.br/atuacao-e-conteudos-de-apoio/legislacao/direitos-

humanos/declar_dir_homem_cidadao.pdf $>$.Acesso em: 17 mar. 2018.

Disponível em: <http://www.onu.org.br/img/2014/09/DUDH.pdf>. Acesso em: 17 mar. 2018.

FERNANDES, Antônio Scarance. Processo penal constitucional. São Paulo: Revista dos Tribunais, 2005.

GOMES FILHO, Antônio Magalhães. Presunção de inocência: Princípio e garantias. Escritos em homenagem a Alberto Silva Franco. São Paulo: Revista dos Tribunais, 2003. p. 121-142.

LOPES, Ana Maria D Ávila; BENÍCIO, Márcio. Análise da decisão judicial sobre "briga de galos" (ADIN nº 1.856/2011) a partir da teoria argumentativa de Neil MacCormick. Revista Brasileira de Direito Animal Comparado, Salvador, v.10, n. 20, p. 37-58, 2015.

MACCORMICK, Neil. Argumentação jurídica e teoria do direito. São Paulo: Martins Fontes, 2006. Argumentación e interpretación en el derecho. DOXA, Cuadernos de Filosofia del Derecho, 2010.

Estado de derecho y rule of law. In: THESING, Josef (Org.). Estado de derecho y democracia. Buenos Aires: Konrad-Adenauer-Stiftung, 1999.p. 101-117.

MACHADO, Hugo de Brito. Garantia constitucional da presunção de inocência e execução da pena antes do trânsito em julgado da decisão condenatória. Interesse Público - IP, Belo Horizonte, ano 18, n. 99, p. 37-45, set./out. 2016.

RAMOS, Gisela Gondin. O princípio da presunção de inocência. Interesse Público - IP, Belo Horizonte, ano 15, n. 77, p. 173-181, jan./fev. 2013.

SCANDELARI, Gustavo Britta. A crise da presunção de inocência e os antecedentes criminais. Revista dos Tribunais, São Paulo, ano 97, v. 873, p. 407-432, 2008.

Trabalho enviado em 10 fevereiro de 2018.

Aceito em 21 de março de 2018. 